\title{
PENDIDIKAN KEAGAMAAN UNTUK MEMBENTUK KERUKUNAN ANTAR UMAT BERAGAMA DI MEDOWO KANDANGAN KEDIRI
}

\author{
Ali Mustofa \\ Sekolah Tinggi Ilmu Tarbiyah Al Urwatul Wutsqo Jombang \\ aljep_90@yahoo.com
}

\section{Naskah Diterima: 24-10-2019 Direvisi: 14-12-2019 Disetujui: 07-02-2020}

\begin{abstract}
Religious education is education that gived knowledge and forms attitude, personality and in practicing religious teaching conducted in their ife. Theta three rel igious adhered by Mendowo people, they are Islam, Hindu, and christian. The eople conducted their religious activities in harmony though they adhere different religion. The research result shows that such religious education in Mendowo village as routinely reitation in mosque, drikir, weekely reitation door to door, giving place for learning alqu'an in each village. It is for Islam. For Hindu, there are legenan, pasraman, and pacalang. Cristian has sunday school in church, door to door worship done in Thrusday which is called spiritial worshipers. The harmony between the ummah can proved by together in worship on the village celebration, helping each other in the moment of holiday each religion, and community self-help on the bouse building, street, grave, and village.
\end{abstract}

Keywords: Building harmony, Relegious Education, Tolerance.

\begin{abstract}
Abstrak
Pendidikan keagamaan adalah pendidikan yang memberikan pengetahuan dan membentuk sikap, kepribadian, dan keterampilan seseorang dalam mengamalkan ajaran agamanya, yang dilaksanakan dalam kehidupan di dunia. Masyarakat Desa Medowo memiliki keberagaman agama antara lain; Islam, Hindu dan Kristen. ditengah perbedaan keyakinan yang dianut, mereka menjalankan aktifitas agama dan dalam kehidupan sehari-hari tetap menjaga kerukunan antar umat beragama. Hasil penelitian menunjukkan bahwa pendidikan keagamaan yang terjadi di desa Medowo dari masingmasing agama adalah pengajian rutinan di musholla/masjid, dzikir bersama umat Islam yang diselingi dengan pengajian setiap seminggu sekali dari rumah ke rumah, setiap dusun ada TPQ (Taman Pendidikan Qur'an), pada umat Hindu ada legenan, Pasraman dan pecalang. Sedangkan umat kristen terdapat sekolah minggu di gereja, pertemuan jama'ah kerohanian setiap kamis yaitu ibadah dari rumah ke rumah secara bergantian. Kerukunanan antar umat beragama dibuktikan dengan setiap perayaan bersih desa (ulang tahun desa) melakukan do'a bersama, pada perayaan hari raya antar umat beragama saling membantu serta gotong royong dalam pembangunan rumah, jalan raya, pemakaman, serta kerja bakti desa.
\end{abstract}

Kata Kunci : Pendidikan Keagamaan, Pembentukan Kerukunan. Toleransi. 


\section{PENDAHULUAN}

Bangsa Indonesia memiliki potensi, watak, karakter, tingkat pendidikan, warna kulit, status ekonomi, kelas sosial, pangkat dan kedudukan, varian keberagaman, cita-cita, perspektif, orientasi hidup, loyalitas organisasi yang berbeda-beda, dari segi kultural maupun struktural, fenomena tersebut mencerminkan adanya keragaman yang tinggi. Tingginya keberagaman bangsa Indonesia, membuat potensi konflik dan perpecahan serta kesalahpahaman juga memiliki eskalasi yang cenderung tinggi ${ }^{1}$.

Keberagaman bangsa Indonesia, juga disebabkan hampir semua agama-agama besar, yakni Islam, Kristen Protestan, Katholik, Hindu, Budha dan Konghucu hidup di negeri ini. Di sisi lain Indonesia juga terdiri dari beragam suku, etnis, budaya dan bahasa. Bentuk negara kepulauan, juga menyebabkan penghayatan dan pengalaman keagamaan bangsa ini unik dibadingkan dengan bangsa-bangsa lain ${ }^{2}$.

Secara ideal, agama merupakan rahmat bagi seluruh alam sebagai bentuk cinta kasih Allah kepada makhluknya ${ }^{3}$. Cinta kasih itulah yang semestinya direfleksikan dalam kehidupan melalui hubungan sosial, agar bisa saling mengenal. Dalam teologi Kristen dikenal istilah credenta dan agenda. Credenta mengacu pada apa yang diimani atau dipercayai, yang dapat diungkapkan melalui pengakuan iman dan konfesi. ${ }^{4}$ Sedangkan agenda menunjukkan pada perilaku dan sikap etis serta moral yang dikerjakan berdasarkan credenta. Konsep teologi Kristen ini juga dimiliki oleh agama- agama lain, (seperti: iman, islam, dan ikhsan dalam Islam). Dengan konsep itu, seharusnya keimanan sesorang pada Tuhannya tidak bisa diwujudkan secara abstrak semata, tetapi harus diwujudkan dalam tindakan kongkrit dalam kehidupan di masyarakat ${ }^{5}$.

1 Mujamil Qomar, "Islam Nusantara: Sebuah Alternatif Model Pemikiran, Pemahaman, Dan Pengamalan Islam," El Harakah (terakreditasi) 17, no. 2 (5 Februari 2016): 198-217, https://doi.org/10.18860/el.v17i2.3345; Mursyid Mursyid, "Internalisasi Nilai Keberagaman Agama Dan Paham Keislaman Di Pondok Pesantren: A Sociological Approaches," Jurnal Kependidikan Islam 5, no. 2 (1 Agustus 2015): 125-48.

2 Umi Sumbulah, Pluralisme agama: makna dan lokalitas pola kerukunan antarumat beragama (UINMaliki Press, 2013); M. Zainuddin, Pluralisme agama dalam analisis konstruksi sosial, Cetakan III (Malang: UIN-Maliki Press, 2014); Ikmal Ikmal, "Internalisasi Nilai-Nilai Pluralisme dalam Pendidikan Islam," Jurnal Pendidikan Islam Iqra' 9, no. 1 (2018).

${ }^{3}$ Haedar Nashir dkk., "Muhammadiyah's Moderation Stance in the 2019 General Election: Critical Views from Within," Al-Jami'ab: Journal of Islamic Studies 57, no. 1 (29 Juni 2019): 1-24, https://doi.org/10.14421/ajis.2019.571.1-24.

4 Kristen Deede Johnson, Theology, political theory, and pluralism: beyond tolerance and difference, Cambridge studies in Christian doctrine, v. 15 (Cambridge, UK; New York: Cambridge University Press, 2007).

5 Arifuddin Ismail, "Refleksi Pola Kerukunan Umat Beragama," Analisa: Journal of Social Science and Religion 17, no. 2 (2010): 175. 
Penelitian Rosidah menyatakan bahwa kerukunan antar umat beragama bukan sekedar di mana tidak ada konflik, tetapi lebih dalam kerukunan mengandung makna hidup dengan saling menghormati, menghargai dalam segala aktifitas ${ }^{6}$. Bentuk lain dari hubungan antar umat beragama dapat dikembangkan lewat kerjasama dalam arti melakukan sesuatu yang dilakukan secara bersama, saling membantu, menghormati, menghargai ${ }^{7}$. Hal ini diharapkan dapat menumbuhkan jiwa persahabatan, persaudaraan, toleransi dan penghargaan, oleh karena itu keberagamaan seseorang atau masyarakat mudah dipengaruhi oleh suasana psikologis dan sosiologis yang melingkupi konteks kehidupan mereka ${ }^{8}$.

Masyarakat Desa Medowo memiliki keberagaman agama antara lain (Islam, Hindu dan Kristen), ditengah perbedaan keyakinan yang dianut mereka tetap menjaga kerukunan antar umat beragama, Kultur dan Budaya masyarakat Medowo saling toleransi, menghormati, dan kerukunan umat beragama sangat terjalin dengan baik. Mereka sadari bahwa hidup di dunia itu pasti membutuhkan satu sama lain dengan pendidikan yang mereka dapat dari masing-masing keyakinan bahwasanya beragama itu mengajarkan mempercayai akan adanya Tuhan dan selain itu berbuat baik antar manusia juga diajarkan, tidak hanya pada umat Islam melainkan agama yang lain, agam Non Islam (Hindu, Kristen) juga mengajarkan seperti halnya orang muslim (Hablum min allah dan Hablum min annas). Yang lebih menarik lagi adalah ada keluarga didesa tersebut yang memiliki agama yang berbeda (keluarga pelangi), akan tetapi bisa berdampingan, tanpa mempermasalahkan urusan kepercayaan dalam beragama. Secara umum keseluruhan bentuk kerukunan di desa Medowo di buktikan dengan adanya kegiatan-kegiatan dalam masyarakat misal ketika lebaran Idul Fitri ketika ada acara takbir keliling masyarakat non muslim membantu mensukseskanya acara pemuda-pemuda Hindu dan Kristen ikut serta mengamankan acara tersebut, dan sebaliknya ketika masyarakat non muslim mempunyai acara Hari Raya Nyepi (Hari Raya Umat Hindu) dan Hari Raya Natal (Hari Raya Umat Kristen) masyrakat Islam juga menghormati dengan tidak membuat kegaduhan/kerusuhan ketika mereka sedang beribadah, ketika mereka membutuhkan

${ }^{6}$ Agus Pramono dan M. Ag Drs. M. Darojat Ariyanto, "Peran Forum Kerukunan Umat Beragama Dalam Membina Kerukunan Antar Umat Beragama (Studi Kasus FKUB Kota Surakarta)" (s1, Universitas Muhammadiyah Surakarta, 2017), http://eprints.ums.ac.id/50007/.

7 Agus Supriyanto dan Amien Wahyudi, "Skala karakter toleransi: konsep dan operasional aspek kedamaian, menghargai perbedaan dan kesadaran individu," Counsellia: Jurnal Bimbingan dan Konseling 7, no. 2 (30 November 2017): 61, https://doi.org/10.25273/counsellia.v7i2.1710.

${ }^{8}$ Sumbulah, Pluralisme agama, 24. 
bantuan untuk mensukseskan acara mereka orang muslim dan yang lainya tidak segansegan untuk menolaknya, karena mereka tidak memperdulikan golongan agama yang mereka anut tetapi mereka mementingkan kebersamaan dan sikap rukun antar umat beragama.

Dengan keberagaman umat beragama di desa tersebut dan pendidikan yang mereka terima dari kegiatan-kegiatan pendidikan yang ada di desa tersebut misal untuk masyrakat muslim mengadakan pengajian rutin di setiap bulannya, perkumpulan jama'ah tahlil \& Yasin setiap minggunya,dsb. Orang non muslim juga memiliki perkumpulan seperti halnya orang Islam, misal acara setiap hari sabtu malam minggu legi (legenan) untuk orang Hindu, setiap hari Minggu waktu beribadah untuk orang Kristen. dengan adanya bekal yang mereka terima dari pengetahuan yang mereka miliki mereka mengahargai akan agama lain yang ada di sekitar, bukan berarti mereka ikut serta dalam beribadah melainkan mereka hanya ikut mengamankan atau mendukung kegiatankegiatan yang diadakan umat beragama, kegiatan-kegiatan desa pun mereka kerjakan bersama misal gotong royong, bersih desa, ulang tahun desa dsb. Jadi tidak terpengaruh dengan adanya perbedaan agama tapi mereka memprioritaskan dengan kerukunan antar umat beragama. Timbul sikap persaudaraan dan toleransi yang kuat, khazanah tersebut juga diharapkan dapat memperkuat bangunan kerukunan antar umat beragama dan dari hasil pendidikan keagamaan yang mereka miliki maka masyarakat desa Medowo akan menjadi panutan bagi desa, daerah dan bangsa yang lain dalam keberagaman umat beragama.

\section{Hakikat Pendidikan Keagamaan}

Pendidikan merupakan kebutuhan pokok bagi manusia, karena manusia disaat dilahirkan tidak mengetahui sesuatu apapun, sebagaimana firman Allah di dalam AlQur'an ${ }^{10}$ yang berbunyi "dan Allah mengeluarkan kamu dari perut ibumu, tidak mengetahui sesuatu" ${ }^{\prime 1}$ Pendidikan merupakan bagian yang tidak dapat dipisahkan dari hidup dan kehidupan manusia. Bagaimanapun sederhana komunitas manusia memerlukan pendidikan ${ }^{12}$. Menurut Marimba menekankan pengertian pendidikan pada pengembangan jasmani dan rohani menuju kesempurnaanya, sehingga terbina kepribadian yang utama,

\footnotetext{
${ }^{9}$ Observasi Pendahuluan tanggal 12 September 2017.

${ }^{10}$ Al-Qur`an (Jakarta: Kementerian Agama RI, 2010), 58:2.

11 Q.S 58: 2

12 Ramayulis, Ilmu Pendidikan Islam (Jakarta: Kalam Mulia, 2013), 28.
} 
suatu kepribadian yang seluruh aspeknya sempurna dan seimbang. Untuk mewujudkan kesempurnaan tersebut dibutuhkan bimbingan yang serius dan sistematis dari pendidik ${ }^{13}$.

Menurut M. Taib Thahir Abdul Muin sebagaimana dikutip oleh Asian Hady, agama adalah: suatu peraturan Tuhan yang mendorong jiwa seseorang yang mempunyai akal memegang peraturan Tuhan dengan kehendaknya sendiri untuk mencapai kebahagiaan hidup dan kebahagiaan kelak di akhirat ${ }^{14}$. Rumusan dan definisi yang telah dikemukakan di atas, jelaslah bahwa agama adalah suatu sistem kepercayaan kepada Tuhan sebagai pencipta, pengawas alam semesta dan penyembahan kepada Tuhan yang didasarkan atas keyakinan tertentu untuk mencapai kebahagiaan hidup dan kebahagiaan kelak di akhirat ${ }^{15}$.

Pendidikan keagamaan adalah pendidikan yang memberikan pengetahuan dan membentuk sikap, kepribadian, dan keterampilan seseorang dalam mengamalkan ajaran agamanya, yang dilaksanakan dalam kehidupan di dunia ${ }^{16}$, Pendidikan keagamaan berfungsi membentuk manusia Indonesia yang beriman dan bertakwa kepada Tuhan Yang Maha Esa serta berakhlak mulia dan mampu menjaga kedamaian dan kerukunan hubungan inter dan antarumat beragama ${ }^{17}$.

Sebuah keyakinan beragama, yang di dalamnya terdapat sekian nilai, kepercayaan, dan aturan normatif, pasti akan sangat memengaruhi kehidupan seseorang, baik dalam berpikir maupun bertindak. Di mana pun berada, orang yang taat beragama, pasti imanya akan hadir dan memberi pertimbangan terhadap semua keputusan yang diambilnya ${ }^{18}$. Ada beberapa cara pandang atau pendekatan untuk mengkaji ajaran agama dan ekspresi keberagamaan. Secara sederhana, aspek-aspek fundamentaldari agama meliputi enam hal: 1) doktrin ketuhanan, 2) Rasul Tuhan sebagai pembawanya, 3) kitab suci yang menghimpun ajaran dasar agama, 3) kitab suci yang menghimpun ajaran dasar agama, 4)

${ }^{13}$ Ahmad D. Marimba, Pengantar Filsafat Pendidikan Islam (P.T. Alma’arif, 1987).

14 Aslam Hady, Pengantar Filsafat Agama (Rajawali, 1986).

${ }^{15}$ Mariasusai Dhavamony, Fenomenologi agama (Yogyakarta: Kanisius, 2006).

16 Perkembangan pabam keagamaan transnasional di Indonesia (Kementerian Agama RI, Badan Litbang dan Diklat, Puslitbang Kehidupan Keagamaan, 2011).

17 Nur Rohmah Hayati, "Pendidikan Pra Sekolah (Pendidikan Anak Usia Dini) Dalam Islam," Aș-Șibyān: Jurnal Pendidikan Anak Usia Dini 1, no. 01 (25 Januari 2017): 72-82; Nur Rohmah dan Dyah Fifin Fatimah, "Pola Pengelolaan Pendidikan Anak Usia Dini Di PAUD Ceria Gondangsari Jawa Tengah," MANAGERIA: Jurnal Manajemen Pendidikan Islam 1, no. 2 (2016): 247-73, https://doi.org/10.14421/manageria.2016.12-05.

18 Agus Ahmad Safei, "Dinamika Sosial Dalam Mewujudkan Toleransi Beragama (Studi Kasus Program Bandung Kota Agamis)" (doctoral, Universitas Padjadjaran, 2012), http://repository.unpad.ac.id/15951/; Casram Casram, "Membangun Sikap Toleransi Beragama dalam Masyarakat Plural," Wawasan: Jurnal Ilmiah Agama dan Sosial Budaya 1, no. 2 (2016): 187-198. 
format dan tata cara ritual, 5) etika sosial, 6) konsep dan keyakinan tentang kehidupan setelah mati.

Dari keenam elemen di atas, doktrin ketuhanan dan estakologi, yaitu doktrin keselamatan hidup setelah mati, menempati posisi paling fundamental, terutama bagi rumpun agama sesmitik, yaitu Yahudi, Kristen, dan Islam. Ketiga agama ini memberi porsi dan penekanan sangat kuat terhadap keselamatan hidup setelah mati yang disimbolkan dengan kata "surga" yang diperhadapkan dengan kesengsaraan atau "neraka". Hakikat surga dan neraka ternyata telah mengundang diskusi dan pembahasan sepanjang sejarah teolog dan filosof. Mereka yakin adanya reward and punishment di akhirat nanti, tetapi berbeda mengenai bentuk dan wujudnya. Aspek lain yang mudah diamati adalah format dan aktivitas ritual. Setiap agama mengajarkan bentuk-bentuk ritual yang kemudian melahirkan konsep tempat suci seperti halnya bangunan masjid, gereja, sinagoge, kelenteng, dan vihara ${ }^{19}$.

Agama sebenanya menekankan pada sikap beragama yang toleran. Dapat bekerja sama membangun perdamaian, keadilan, harmoni, dan bepartisipasi aktif dalam berbagai kegiatan kemanusiaan (beyond the wall). Sebuah pelaksanaan dari sebuah rencana yang diatur dalam Kegiatan Pendidikan keagamaan, melalui aktivitas atau tindakan untuk mencapai tujuan kegiatan keagamaan ${ }^{20}$.

\section{Pembentukan Kerukunan Antar Umat Beragama}

Kerukunan antar umat beragama

Kerukunan beragama berkaitan dengan toleransi, yakni istilah dalam konteks sosial, budaya dan agama berati sikap dan perbuatan yang melarang adanya diskriminasi terhadap kelompok-kelompok yang berbeda atau tidak dapat diterima oleh mayoritas dalam suatu masyarakat. Toleransi memiliki peranan penting dalam pluralisme saat ini, tidak hanya dipahami sebagai etika yang mengatur hubungan antar kelompok agama, akan tetapi juga yang terpenting adalah adanya kepekaan baru untuk sepenuhnya menghargai keberagaman. Dalam kenteks ini, tranformasi internal agama tidak hanya pada aspek doktrin-teologin akan tetapi juga diperlukanya transformasi pada aspek cultural-sosiologis untuk menghormati dan menghargai keberadaan dan hak-hak kelompok lain ${ }^{21}$.

${ }^{19}$ Komaruddin Hidayat, Psikologi Beragama (Hikmah, 2007).

20 Anthony Reid, "Religious Pluralism or Conformity in Southeast Asia's Cultural Legacy," Studia Islamika 22, no. 3 (2015): 387-404; Bashori Bashori, "Modernisasi Lembaga Pendidikan Pesantren Perspektif Azyumardi Azra," Nadwa 11, no. 2 (17 November 2017): 269, https://doi.org/10.21580/nw.2017.11.2.1881.

21 Toto Suryana, "Konsep dan Aktualisasi Kerukunan Antar Umat Beragama," Jurnal Pendidikan Agama Islam 9, no. 2 (2011): 127-136. 


\section{Toleransi dalam persepektif Agama-Agama}

Toleransi memiliki makna dua sisi, setiap umat Islam harus memiliki keyakinan dan kefanatikan yang kuat terhadap akidahnya, bahwa tidak ada sekutu bagi Allah dan tidak ada sembahan selain Allah ${ }^{22}$. Di sisi lain Islam diharuskan memahami dan menghargai pemeluk agama lain, hal itu karena hidayah dari Allah itu tidak diberikan pada semua orang dan karenanya pula tidak ada paksaan dalam memasuki agama Islam. Agama Islam menekankan toleransi, yakni pemahaman dan pemantapan terhadap agamanya masing-masing, serta menghargai agama lain. Terjadinya disharmoni agama lain yang tidak konsekuen dalam mengamalkan semua ajaranya. Menjaga kerukunan dan keharmonisan hidup adalah sebuah keharusan yang diajarkan $\operatorname{Islam}^{23}{ }^{24}$

Pola kerukunan

Perbedaan agama adalah fenomena nyata yang ada dalam kehidupan. Kebebasan beragama pada hakikatnya adalah dasar terciptanya kerukunan antar umat beragama, tanpa kebebasan beragama tidak mungkin ada kerukunan antar umat beragama, kebebasan beragama adalah hak setiap manusia ${ }^{25}$. Demikian ini adalah beberapa pola yang dikembangkan dalam menciptakan kerukunan antar umat beragama:

Dialog dan kerjasama antar umat beragama.

Hal ini terbukti bahwa perbedaan agama tidak menjadi hambatan bagi terjadinya interaksi sosial, demi mewujudkan keharmonisan dalam keragaman. Terkait hal tersebut masyarakat secara internal tetap meyakini kebenaran agama yang diyakini masing-masing, sementara secara eksternal mereka juga mengakui dan menghargai agama lain.

Perlunya dialog dan kerjasama dalam membentuk kerukunan antarumat beragama, didasarkan pada argumentasi bahwa kerukunan antar umat beragama sejatinya bukan sekedar di mana tidak ada konflik, tetapi mengandung makna bahwa hidup dalam

22 C. W. Von Bergen, "Misconstrued tolerance: issues for multicultural and diversity training," Development and Learning in Organizations: An International Journal 27, no. 2 (8 Februari 2013): 9-12, https://doi.org/10.1108/14777281311302021; Tom Farer, "The Clash of Cultures, the Tension Within Liberalism, and the Proper Limits of Tolerance," Human Rights Quarterly 36, no. 1 (2014): 1-21, https://doi.org/10.1353/hrq.2014.0016; Rina Hermawati, Caroline Paskarina, dan Nunung Runiawati, “Toleransi Antar Umat Beragama di Kota Bandung," Indonesian Journal of Anthropology 1, no. 2 (23 Maret 2017), https://doi.org/10.24198/umbara.v1i2.10341.

${ }^{23}$ Sumbulah, Pluralisme agama, 162.

${ }^{25}$ Sumbulah, Pluralisme agama. 
konteks pluralitas harus menjunjung tinggi prinsip saling menghormati dan menghargai dalam segala aktivitas ${ }^{26}$.

Bentuk lain dari hubungan antar umat beragama dimaksud dapat dikembangkan melalui kerjasama, dengan cara melakukan sesuatu secara bersama-sama antarumat beragama, saling membantu, menghargai dan menjunjung prinsip toleransi (tasamuh) ${ }^{27}$. Dalam melaksanakan toleransi antar umat beragama kita harus mempunyai sikap atau prinsip untuk mencapai kebahagiaan dan ketentraman. Adapun prinsip-prinsip tersebut menurut Said Aqil Al Munawar ${ }^{28}$ :

1) Kesaksian yang jujur dan saling menghormati (frank witness and mutual respect).

Semua pihak dianjurkan membawa kesaksian yang terus terang tentang kepercayaanya di hadapan Tuhan dan sesamanya, agar keyakinannya masingmasing tidak ditekan ataupun dihapus oleh pihak lain. Dengan demikian rasa curiga dan takut dapat dihindarkan serta semua pihak dapat menjauhkan perbandingan kekuatan tradisi masing-masing yang dapat menimbulkan sakit hati dengan mencari kelemahan pada tradisi keagamaan lain.

2) Prinsip kebebasan beragama (religius freedom). Meliputi prinsip kebebasan perorangan dan kebebasan sosial (individual freedom and social freedom).

Kebebasan individual sudah cukup jelas setiap orang mempunyai kebebasan untuk menganut agama yang disukainya, bahkan kebebasan untuk pindah agama. Tetapi kebebasan individual tanpa adanya kebebasan sosial tidak ada artinya sama sekali. Jika seseorang benar-benar mendapat kebebasan agama, ia harus dapat mengartikan itu sebagai kebebasan sosial, tegasnya supaya agama dapat hidup tanpa tekanan sosial. Bebas dari tekanan sosial berarti bahwa situasi dan kondisi sosial memberikan kemungkinan yang sama kepada semua agama untuk hidup dan berkembang tanpa tekanan.

3) Prinsip penerimaan (Acceptance)

Yaitu mau menerima orang lain seperti adanya. Dengan kata lain, tidak menurut proyeksi yang dibuat sendiri. Jika kita memproyeksikan

\footnotetext{
${ }^{26}$ Syamsul Arifin, "Islamic religious education and radicalism in Indonesia: strategy of de-radicalization through strengthening the living values education," Indonesian Journal of Islam and Muslim Societies 6, no. 1 (1 Juni 2016): 93, https://doi.org/10.18326/ijims.v6i1.93-126; Masdar Hilmy, "Whither Indonesia's Islamic Moderatism? A Reexamination on the Moderate Vision of Muhammadiyah and Nu," Journal of Indonesian Islam 7, no. 1 (1 Juni 2013): 24-48, https://doi.org/10.15642/JIIS.2013.7.1.24-48.

27 Sumbulah, Pluralisme agama, 196.

28 Said Aqil Husin Al Munawar, Hasan M. Noer, dan Musyafaullah, Hukum Islam dan pluralitas sosial (Penamadani, 2004).
} 
penganut agama lain menurut kemauan kita, maka pergaulan antar golongan agama tidak akan dimungkinkan. Jadi misalnya seorang Kristen harus rela menerima seorang penganut agama Islam menurut apa adanya, menerima Hindu seperti apa adanya.

4) Berfikir positif dan percaya (positive thinking and trustwortby).

Orang berpikir secara "positif "dalam perjumpaan dan pergaulan dengan penganut agama lain, jika dia sanggup melihat pertama yang positif, dan yang bukan negatif. Orang yang berpikir negatif akan kesulitan dalam bergaul dengan orang lain. Sedangkan prinsip "percaya" menjadi dasar pergaulan antar umat beragama. Selama agama masih menaruh prasangka terhadap agama lain, usaha-usaha ke arah pergaulan yang bermakna belum mungkin. Sebab kode etik pergaulan adalah bahwa agama yang satu percaya kepada agama yang lain, dengan begitu dialog antar agama antar terwujud ${ }^{29}$.

Hadits Nabi SAW ${ }^{30}$ :

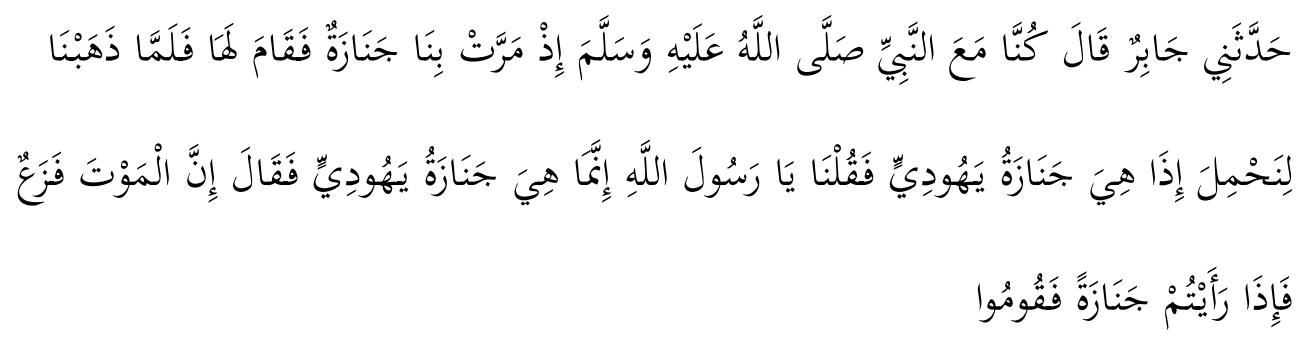

"Diriwayatkan dari Jabir bin Abdullah r.a: Jenazah (yang diusung ke pemakaman) lewat dihadapan kami. Nabi Muhammad Saw berdiri dan kami pun berdiri. Kami berkata, "Ya Rasulullah ini jenazah orang Yahudi" Ia berkata," Kapanpun kalian melibat jenazah (yang diusung ke pemakaman), berdirilah." 31

Dari Hadits tersebut jelas bahwa Nabi Muhammad tidak pernah membeda-bedakan, sikap toleransi itu direfleksikan dengan cara saling

29 Zuhairi Misrawi, Mira Rainayati, dan Anjelita Noverina, Al-Quran kitab toleransi: tafsir tematik Islam rahmatan lil'âlamîn (Jakarta: Pustaka Oasis, 2010); Khotimatul Husna, Imam Ghozali, dan Dzulmanni, 40 hadits shabih: terapi nabi mengikis terorisme: teladan menebar kedamaian dan toleransi di muka bumi (Yogyakarta: Pustaka Pesantren, 2011).

${ }^{30}$ Muhammad bin Ismail Abu Abdullah, Shahih Bukhari, 4 ed., 1 vol. (Beirut Lebanon: Dar al-Kotob AlIlmiyah, 2010).

${ }^{31}$ Lidwa Pustaka i-Sofware- Kitab 9 Imam Hadist. 
menghormati, saling memuliakan dan saling tolong-menolong. Jadi sudah jelas, bahwa sisi aqidah atau teologi bukanlah urusan manusia, melainkan Tuhan SWT dan tidak ada kompromi serta sikap toleran di dalamnya. Sedangkan kita bermu ee amalah dari sisi kemanusiaan kita.

\section{Membalas perbuatan buruk dengan perbuatan baik}

Pola yang dikembangkan untuk kerukunan antar umat beragama adalah dengan membalas perbuatan buruk dengan perbuatan baik. Hal ini sebagaimana ajaran Islam: jika orang itu memusuhi kamu, maka janganlah kamu memusuhinya, maka balaslah permusuhan itu dengan hal yang baik, karena Allah tidak pernah mengajarkan permusuhan, dianjurkan berbuat baik kepada bersama ${ }^{32}$.

Allah berfirman dalam QS.Al-Hujurat ayat ${ }^{33} 10$ :

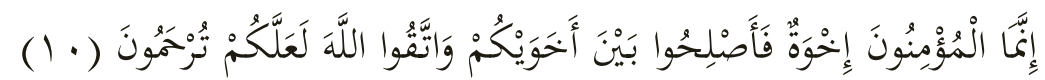

10.orang-orang beriman itu Sesunggubnya bersaudara. sebab itu damaikanlah (perbaikilah bubungan) antara kedua saudaramu itu dan takutlah terbadap Allah, supaya kamu mendapat rahmat.

Dalam ayat di atas, Allah menyatakan bahwa orang-orang mu'min bersaudara, dan memerintahkan untuk melakukan ishlah (perbaikan hubungan) jika seandainya terjadi kesalahpahaman diantara 2 orang atau kelompok kaum muslim, Al-Qur'an memberikan contoh-contoh penyebab keretakan hubungan sekaligus melarang setiap muslim melakukanya.

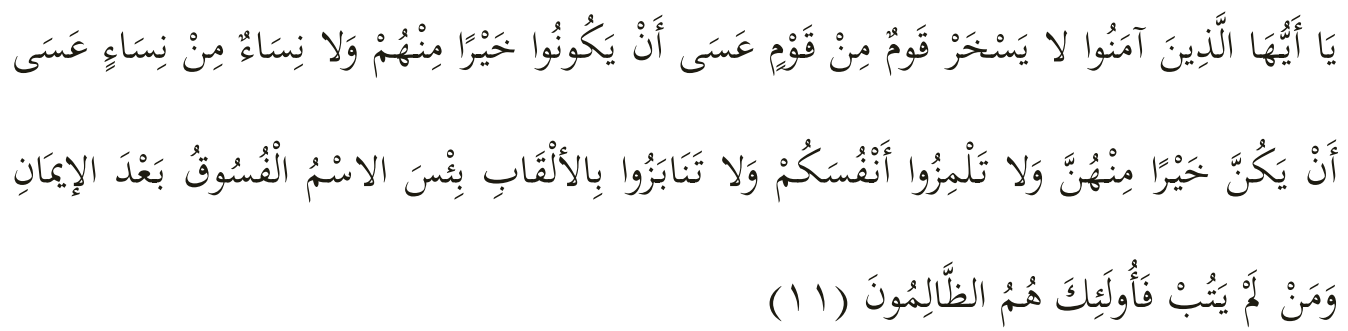

11. Hai orang-orang yang beriman, janganlah sekumpulan orang laki-laki merendabkan kumpulan yang lain, boleh Jadi yang ditertawakan itu lebih baik dari mereka. dan jangan

32 Sumbulah, Pluralisme agama, 151

33 Al-Qur`an, Hujurat 10. 
pula sekumpulan perempuan merendabkan kumpulan lainnya, boleh Jadi yang direndabkan itu lebih baik. dan janganlah suka mencela dirimu sendiridan jangan memanggil dengan gelaran yang mengandung ejekan. seburuk-buruk panggilan adalah (panggilan) yang buruk. sesudah iman dan Barangsiapa yang tidak bertobat, Maka mereka Itulah orang-orang yang ralim.

Ayat tersebut juga memerintahkan orang mu'min untuk menghindar prasangka buruk, tidak mencari-cari kesalahan orang lain, serta menggunjing yang diibaratkan al-Qur'an seperti memakan daging saudara sendiri yang telah meninggal dunia. Dan menyadari pula bahwa kita semua adalah bersaudara, maka akan timbul rasa kasih sayang, saling pengertian.

\section{Peningkatan Territorial Approach (pendekatan wilayah)}

Umi Sumbulah menyatakan bahwa pola yang dikembangkan dalam membina kerukunan antar umat beragama adalah dengan Territorial Approach (pendekatan wilayah). Contohnya dalam hal keamanan dengan ikut berjaga malam bersama warga, menghadiri undangan pernikahan, khitanan menjenguk orang sakit, takziyah, bersilaturrahim kepada para tokoh agama, khususnya pada eventevent tertentu. Mengunjungi umat lain yang merayakan hari besarnya, misal Hindu saling mengunjungi umat lain yang merayakan hari raya seperti Natal dan Idul Fitri, sebailknya ketika hari raya Nyepi Umat Islam dan Kristiani juga mengunjungi umat Hindu ${ }^{34}$.

Disamping itu, menjaga komunikasi dengan baik agar saling mengenal dan tidak terjadi fanatisme terhadap agama sendiri juga penting dilakukan, dengan demikian umat diharapkan tidak mudah terprovokasi oleh isu-isu yang tidak bertanggung jawab, yang dapat memecah-belah hubungan antarumat beragama. Dalam konteks perayaan hari besar yang intinya adalah penyucian, menjelaskan agama Hindu yang merayakan hari raya Nyepi yang dalam ajaranya merupakan penyucian (Taur Agung) 35 .

\section{Layanan Kesehatan}

Layanan kesehatan merupakan salah satu pola penting yang harus dikembangkan dalam membina kerukunan antara umat beragama. Dalam konteks ini, menyelenggarakan layanan kesehatan dengan melibatkan sejumlah dokter 
dengan latar belakang lintas agama. Layanan diberikan diantaranya adalah melalui penanganan medis, sebagai bentuk dari penciptaan kerukunan, dengan kerja sosial seperti ini, umat beragama tidak saja dituntut untuk bersama-sama mengoreksi citra dan kesan keliru yang tergambar dalam benak masing-masing, tetapi lebih dari itu, dapat menjalin kerja sama konstruktif.

Pementasan Kesenian

Keberhasilan pola kerukunan umat beragama melalui pentas seni ini di antaranya dapat diukur dengan adanya sikap saling mengenal dan mengetahui berbagai kesenian, dan kebersediaan saling tenggang rasa antara satu dengan yang lain.

\section{Meyakini agama sendiri dan menghargai agama orang lain}

Dengan cara memegang secara teguh keyakinan dan agama masingmasing. Secara universal, Islam adalah agama yang sangat menjunjung tinggi toleransi. Bahkan Nabi Muhammad tidak pernah mengajarkan dan merestui umatnya menyerang dan menghina keyakinan agama lain ${ }^{36}$. Islam secara tegas memberikan kebebasan sepenuhnya kepada manusia dalam masalah agama dan keberagamaan. ${ }^{37}$

Mengenai sistem agama yang berbeda-beda, al-Qur'an menjelaskan pada ayat terakhir dalam surat Al-Kafirun:

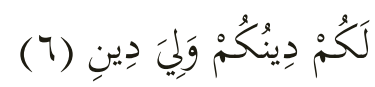

6. untukemu agamamu, dan untukeklah, agamaku. ${ }^{138}$

Bahwa prinsip menganut agama tunggal merupakan suatu keniscayaan. Tidak mungkin manusia menganut beberapa agama dalam waktu yang sama, atau mengamalkan ajaran dari berbagai agama secara silmutan. Oleh sebab itu, alQur'an menegaskan bahwa umat islam tetap berpegang teguh pada sistem keEsaan Allah secara mutlak, sedangkan orang kristen, Hindu pada ajaran ketuhanan yang ditetapkapkanya sendiri. Dalam ayat lain Allah juga menjelaskan tentang prinsip dimana setiap pemeluk agama mempunyai sistem dan ajaran masingmasing sehinga tidak saling hujat-menghujat.

"lanaa a'maluna walakum a'malukum"

36 Sumbulah, 206.

37 Ibid, 154.

${ }^{38} \mathrm{Al}$-Qur`an. 
Pada taraf ini konsepsi tidak menyinggung agama kita dan agama selain kita, juga sebaliknya. Dalam masa kehidupan dunia, dan untuk urusan dunia, semua haruslah kerjasama untuk mencapai keadilan, persamaan dan kesejahteraan manusia. Sedangkan untuk urusan akhirat, urusan petunjuk dan hidayah adalah hak mutlak Tuhan SWT. Maka dengan sendirinya kita tidak sah memaksa kehendak kita kepada orang lain untuk menganut kita.

\section{Do'a Bersama}

Doa bersama merupakan salah satu medan budaya yang dapat mendukung kerukunan umat beragama. Hal ini misalnya kegiatan doa bersama yang dilakukan pada saat perayaan HUT RI tersebut, dilaksanakan sebagai rasa syukur kehadirat Tuhan Yang Maha Kuasa atas rahmat yang telah diberikan kepada seluruh umat manusia. Doa bersama yang dihadiri oleh para pemuka dari berbagai agama menunjukkan adanya persatuan yang kokoh, demi kemajuan bangsa Indonesia, yang diungkapkan dalam doa menurut agama dan keyakinan masing-masing. ${ }^{39}$

\section{Pendidikan Keagamaan Dalam Pembentukan Kerukunan Antar Umat Beragama}

Kerukunan antar umat beragama menurut Rosidah yang dikutip Umi Sumbulah ialah bukan sekedar tidak ada konflik, tetapi lebih dalam kerukunan mengandung makna hidup dengan saling menghormati, menghargai dalam segala aktifitas. Bentuk lain dari hubungan antarumat beragama dikembangkan lewat kerjasama dalam arti melakukan sesuatu yang dilakukan secara bersama, saling membantu, menghormati, menghargai. Hal ini banyak manfaatnya karena secara tidak langsung memberikan frekuensi pertemuan menjadi sering untuk menciptakan kebersamaan. Hal ini diharapkan dapat menumbuhkan jiwa persahabatan, persaudaraan, toleransi dan penghargaan. Oleh karena keberagaman seseorang masyarakat mudah dipengaruhi oleh suasana psikologis dan sosiologis yang melingkupi konteks kehidupan mereka. ${ }^{40}$

Islam sama sekali tidak menafikan agama-agama lain, islam mengakui eksitensi agama-agama tersebut dan tidak menolak nilai-nilai ajaranya. Melindungi tempat-tempat ibadah semua agama tertera dalam QS: Al-Hajj : 40

\footnotetext{
39 Ibid: $195-209$.

40 Ibid: 24.
} 


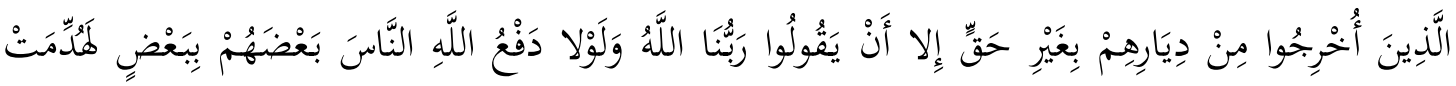

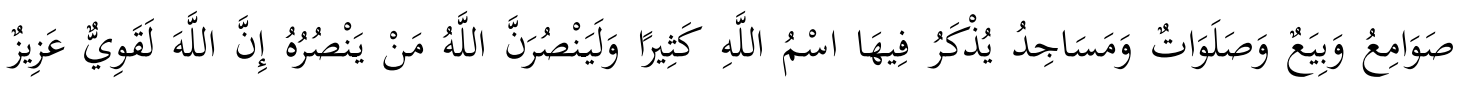

Artinya : (yaitu) orang-orang yang telah diusir dari kampung balaman mereka tanpa alasan yang benar, kecuali karena mereka berkata: "Tuhan Kami hanyalah Allab". dan Sekiranya Allah tiada menolak (keganasan) sebagian manusia dengan sebagian yang lain, tentulah telah dirobohkan biara-biara Nasrani, gereja-gereja, rumah-rumah ibadat orang Yabudi dan masjid- masjid, yang di dalamnya banyak disebut nama Allah. Sesunggubnya Allab pasti menolong orang yang menolong (agama)-Nya. Sesunggubnya Allab benar-benar Maha kuat lagi Maba perkasa. ${ }^{42}$

Dalam konteks ini, komunitas antar umat beragama yang berbeda-beda itu bisa saling bertemu dalam kehidupan sehari-hari. Mereka berinteraksi dan berbaur dalam segala jenis dan aktivitas kemasyarakatan secara moral. Mereka melakukan kerjasama dalam berbagai bidang kegiatan sosial tanpa memandang identitas agama masing-masing. Sebagai contoh ketika kepala desa atau ketua rukun tetangga memimpin membersihkan parit misalnya, semua anggota masyarakat dalam wilayah RT tersebut dilibatkan karena keanggotaanya sebagai warga, dan bukan karena kesamaan dan identitas agama tertentu. Agama bukan tidak memiliki relevansi dalam bentuk kegiatan semacam itu, tetapi justru karena agama mengajarkan kebaikan dan mendorong umatnya berbuat kebajikan sebagai amal shaleh, sebagaimana terlihat pada kegiatan dan aktivitas kemasyarakatan dimaksud. ${ }^{43}$

Kerukunan umat beragama yang dibentuk melalui pendidikan keagamaan, dengan pengajaran bertoleransi, saling pengertian, saling menghormati, saling menghargai dalam kesetaraan pengamalan ajaran agamanya dan kerja sama dalam kehidupan masyarakat.

Kerukunan antar umat beragama dapat diwujudkan dengan:

1. Saling tenggang rasa, saling menghargai, toleransi antar umat beragama

2. Tidak memaksakan seseorang untuk memeluk agama tertentu

\footnotetext{
${ }^{41}$ QS: AL-Hajj : 40

$42 \mathrm{Al}$-Qur`an Al Haj 40.

${ }^{43}$ Sumbulah, Pluralisme agama, 190.
} 
3. Melaksanakan ibadah sesuai agamanya, dan

4. Mematuhi peraturan keagamaan baik dalam Agamanya maupun peraturan negara atau pemerintah.

Dengan demikian akan dapat tercipta keamanan dan ketertiban antar umat beragama ketentraman dan kenyamanan di lingkungan masyarakat berbangsa dan bernegara. Peranan pendidikan dalam sebuah keluarga sangatlah dominan, hal ini dikarenakan masa depan anak akan lebih terjamin jika pendidikanya terpenuhi, baik itu pendidikan umum maupun pendidikan agama. Dari orang tua ada dorongan moral dan spiritual, serta fasilitas keagamaan dirumah ${ }^{44}$.

Dalam masyarakat heterogen terhadap masalah agama dan beberapa hal lain, sikap terbuka dan lebih toleran sangatlah dibutuhkan untuk membentuk suatu masyarakat yang aman, tentram dan damai. Hal itu dapat dimulai dari kehidupan masyarakat yang kecil yaitu keluarga untuk menumbuhkan sikap rukun dan toleran terhadap perbedaan agama yang ada disekitarnya.

\section{ANALISIS dan DISKUSI}

\section{Pendidikan keagamaan dalam pembentukan kerukunan di Desa Medowo Kecamatan Kandangan Kabupaten Kediri.}

Pembentukan kerukunan yang ada di desa medowo melalui pendidikan keagamaan. Proses atau usaha dan kegiatan desa yang dilakukan secara berdaya guna untuk memperoleh yang lebih baik, mendirikan atau mengusahakan supaya lebih baik, lebih maju dan lebih sempurna. Masyarakat yang mempunyai keyakinan berbeda-beda, dengan berkembangnya agama melalui proses pendidikan keagamaan yang mereka jalani dalam keseharianya, maka akan mempengaruhi interaksi dan hubungan sosial yang baik antar agama, demikian proses pendidikan keagamaan yag ada di desa Medowo tidak secara formal, namun ada rutinan setiap hari, setiap minggu, setiap bulan, dan sebagainya, masing-masing agama dipimpin oleh tokoh agama dan di tempat ibadahya masingmasing, pelaksanaan ibadah yang dilakukan setiap agama memiliki sistem yang berbedabeda, umat Islam di mushola/TPA(Taman Pendidikan AlQur'an) untuk anak-anak dan remaja masjid rutinanya yaitu sholawatan,untuk ibu-ibu dan bepak-bapak setiap minggu tausiyah pada jama'ah tahlil di masjid/ dari rumah-kerumah, umat Hindu ada rutinan setiap harinya di Pure, prasaman setiap satu minggu sekali, dan legen setiap jum'at legi

${ }^{44}$ Benedict, Truth and Tolerance: Christian Belief and World Religions (San Francisco: Ignatius Press, 2004); Jacob Neusner dan Bruce Chilton, ed., Religious tolerance in world religions (West Conshohocken, Pa: Templeton Foundation Press, 2008). 
pada malam purnama, umat Kristen ada rutinan setiap minggu (sekolah minggu) dan setiap kamis yaitu ibadah dari rumah kerumah secara bergantian(ibadah keluarga).

Pendidikan keagamaan khususnya pendidikan kerohanian itu mereka lakukan dengan sedemikian rupa, memimpin umat agar bertaqwa kepda Tuhan, dari segi masyarakat bisa menjadi orang-orang yang diterima masyarakat menjadi orang yang baik dan berakhlak baik. Materi yang disampaikan dalam proses pendidikan keagamaan sesuai dengan keyakinan masing-masing, yang pada inti dari pembahasan yaitu tentang keesaan Tuhan dan bagaimana cara bersosial dalam bermasyarakat yang berbeda agama yang ada di desa medowo.

Proses kegiatan yang ada saling mendukung antar Agama dalam semua kegiatan keagamaan di Desa medowo, dalam artian ketika agama lain sedang melakukan ibadah maka kita tidak menganggu dan mempersilahkanya. Misal dalam pelaksanaan Nyepi bagi umat Hindu maka tetangga yang bukan non Hindu ikut menghargai dan mengormati dengan tidak membuat gaduh atau keramaian disekitarnya. Karena dalam keyakinan masing-masing tidak boleh menganggu orang lain dalam beribadah, saling mendatangi bila diundang, misalnya pernikahan, khitanan, tasyakuran dan lain sebagainya. Bentuk toleransi meliputi dua aspek yaitu spiritual dan ceremony, spiritual biasanya ada kegiatan agama, berati di dalamnya tokoh agama di undang untuk mengikuti kegiatan besar, ceremonialnya masyarakat saling mengunjungi untuk menghormati agama lain.

Dengan adanya seperti itu maka kerukunan lah yang terjalin dari proses kegiatan pendidikan yang mereka miliki selama mereka belajar agama dengan sungguh-sungguh. Berhubungan baik dengan Tuhan dan Manusia untuk mencapai kebahagiaaan hidup dan kebahagiaan kelak di akhirat. Paparan di atas sesuai dengan teori menurut Umi Sumbullah menyatakan bahwa; semua agama mempunyai tujuan pendidikan keagamaan yang sama yaitu sebagai pedoman atau arah yang hendak dicapai dalam pelaksanaan aktivitas keagamaan. Kegiatan tanpa tujuan dibaratkan membuat rumah tanpa pondasi.Tujuan akhir. Pendidikan keagamaan ialah membentuk sebuah kegiatan yang dapat mengajak pemeluknya untuk selalu beriman dan mengamalkan segala perbuatan yang ma'ruf yakni dengan menjaga keselarasan hubungan antara dirinya dengan Tuhan dan berkeseimbangan hubungan antar agama satu dengan yang lain.

Sikap keberagamaan yang juga dapat memicu konflik dan menghancurkan kerukunan umat beragama adalah terjadinya pendangkalan agama, sebagai umat islam tidak hanya menyangkut ibadah shalat saja, namun juga berkhlak baik yang merupakan 
suri teladan dari Rasallah SAW. Rasul diutus Allah SWT salah satu untuk menyempurnakan akhlak, supaya manusia mempunyai akhlak yang baik ${ }^{45}$.

Mengingat keberagaman (heterogenitas) merupakan realita dan ketentuan dari Allah Tuhan semesta alam maka bagi manusia tidak ada alternatif lain, kecuali menerima dan memelihara dengan mengarah kepada kepentingan dan tujuan bersama, dan apabila tidak dipelihara dengan baik dapat saling bergesekan sehingga terjadi perpecahan, dan tidak mustahil mengarah kepada separatisme. Tetapi karena bangsa Indonesia adalah bangsa yang religius dan menyadari bahwa keberagaman ini merupakan ketentuan atau takdir dari Allah Yang Maha pengatu alam, maka insan Indonesia menggalang dan membina persatuan bangsanya, bukan hanya itu, dari keberagaman ini pulalah dihimpun hasrat-hasrat yang ada menjadi hasrat kolektif dalam membangun, memelihara kesatuan dan keutuhan bangsa dan negara.

Kerukunan hidup umat beragama bukan berati merelatifir agama-agama yang ada dengan melebur kepada satu totalitas (sinkretisme agama) dengan menjadikan agamaagama yang ada itu sebagai unsur dari agama totalitas itu. Dengan kerukunan dimaksudkan agar terbina dan terpelihara hubungan baik dalam pergaulan antar warga yang berlain agama. Urgensi kerukunan adalah untuk mewujudkan kesatuan pandangan dan kesatuan sikap, guna melahirkan kesatuan perbuatan dan tindakan serta tanggung jawab bersama, sehingga tidak ada pihak yang melepaskan diri dari tanggung jawab atau menyalahkan pihak lain ${ }^{46}$.

Kerukunan beragama berkaitan dengan toleransi, yakni istilah dalam konteks sosial, budaya dan agama berati sikap dan perbuatan yang melarang adanya diskriminasi terhadap kelompok-kelompok yang berbeda atau tidak dapat diterima oleh mayoritas dalam suatu masyarakat. Toleransi memiliki peranan penting dalam pluralisme saat ini, tidak hanya dipahami sebagai etika yang mengatur hubungan antar kelompok agama, akan tetapi juga yang terpenting adalah adanya kepekaan baru untuk sepenuhnya menghargai keberagaman. Dalam kenteks ini, tranformasi internal agama tidak hanya pada aspek doktrin-teologin akan tetapi juga diperlukanya transformasi pada aspek cultural-sosiologis untuk menghormati dan menghargai keberadaan dan hak-hak kelompok lain. ${ }^{47}$ Di sisi lain Islam diharuskan memahami dan menghargai pemeluk agama lain, hal itu karena hidayah dari Allah itu tidak diberikan pada semua orang dan karenanya pula tidak ada paksaan

45 Sumbulah, Pluralisme agama, 161.

${ }^{46}$ Suryana, "Konsep dan Aktualisasi Kerukunan Antar Umat Beragama."

${ }^{47}$ Suryana. 
dalam memasuki agama Islam. Agama Islam menekankan toleransi, yakni pemahaman dan pemantapan terhadap agamanya masing-masing, serta menghargai agama lain. Terjadinya disharmoni agama lain yang tidak konsekuen dalam mengamalkan semua ajaranya. Menjaga kerukunan dan keharmonisan hidup adalah sebuah keharusan yang diajarkan Islam $^{48}$.

Teori tersebut sesuai dengan pendidikan keagamaan dalam kerukunan di desa Medowo kecamatan Kandangan yang mana toleransi menurut para tokoh agama masingmasing mempunyai pengertian yang berbeda. Menurut tokoh agama Islam di desa Medowo bahwa toleransi adalah saling menghormati bila kegiatan keagamaan dilaksanakan, misal umat Hindu melaksanakan ibadah Nyepi maka umat Islam dan Kristen menghormati mereka beribadah dngan tidak membikin gaduh, saling mendatangi bila diundang ketika pernikahan, khitanan, tayakuran dan lain sebagainya.

Menurut tokoh agama Kristen yang ada di desa Medowo toleransi itu saling mengasihi, saling membantu, saling menolong tanpa memandang agama, sikap hidup kemanusiaan satu dengan yang lain ditunjukan dengan kerukunan, saling menghargai, saling menghormati, di dalam kitab Injil yang menejelaskan tentang toleransi di dalam MASMUR pasal 133, yaitu: sungguh alangkah baiknya dan indahnya apabila saudarasaudara diam bersama dengan kerukunan. Hidup rukun berkat Tuhan akan turun atas dia, maksudnya bagi siapa yang hidup rukun pasti diberkati.

Sedangkan menurut tokoh agama Hindu menyatakan bahwa toleransi dalam agama Hindu di dalam kitab wedha yang menjelaskan toleransi ada namanya "tattwam asih" artinya saya adalah kamu, kamu adalah saya. Bila kita merasa sakit tentunya kita tidak menyakiti orng lain, orang lain senang kita ikut senang, kalau kamu tidak mau menyakiti orang lain maka kamu jangan menyakiti orang lain.

\section{Kerukunan antar Umat Beragama di Desa Medowo Kecamatan Kandangan Kabupaten Kediri}

Pola kerukanan yang ada di desa Medowo menurut Saningrat berjalan dengan baik, realita yang ada adalah pada saat perayaan tawuragung perayan umat Hindu, tidak ada komando masyarakat Islam dan Kristen membantu dalam hal keamanan, padahal

48 Sumbulah, Pluralisme agama; Hamlan Andi Baso Malla, "Pembelajaran Pendidikan Agama Islam Berbasis Multikultural Humanistik Dalam Membentuk Budaya Toleransi Peserta Didik Di SMA Negeri Model Madani Palu, Sulawesi Tengah," INFERENSI: Jurnal Penelitian Sosial Keagamaan 11, no. 1 (1 Juni 2017): 163-86, https://doi.org/10.18326/infsl3.v11i1.163-186; Muhammad Anas Ma`arif, "Internalisasi Nilai Multikulutural Dalam Mengembangkan Sikap Toleransi ( Studi Di Di Pesantren Mahasiswa Universitas Islam Malang)," Ną̧hruna: Jurnal Pendidikan Islam 2, no. 1 (24 Maret 2019), https://doi.org/10.31538/nzh.v2i1.179. 
tidak ada perintah atau komando dari atasan, dan sebaliknya jika acara orang kristen maka pemuda islam dan hindu ikut membantu dalam hal keamanan, orang Islam juga begitu ketika mengadakan pengajian rutinan kadang umat hindu dan kristen menyumbang air mineral. Kerukunan yang lain yaitu muamalah, pergaulan, gotong royong. Mereka tidak membedakan status agama, entah itu kristen hindu ataupun Islam. Maka perlunya dialog dan kerjasama dalam membentuk kerukunan antar umat beragama. Pola kerukunan yang ada di desa medowo sangat bagus dalam kegiatan gotong royong, ada keterlibatan dalam hal keamanan misal dalam acara takbir keliling maka masyarakat hindu dan kristen menjadi keamanan, dan sebaliknya jika masyarakat kristen dan hindu ada acara besar yang menjadi petugas keamanan adalah pemuda hindu dan islam. Saling menghormati bila kegiatan keagamaan misal umat hindu melaksanakan ibadah nyepi berati kita sebagai umat muslim menghormati dengan cara tidak bikin gaduh, saling mendatangi bila diundang, misalnya pernikahan, khitanan, tasyakuran dan lain sebagainya. Hal ini sesuai dengan teori pola kerukunan pendekatan terroterial Approach (pendekatan wilayah) yaitu Umi Sumbulah menyatakan bahwa pola yang dikembangkan dalam membina kerukunan antar umat beragama adalah dengan Territorial Approach (pendekatan wilayah). Contohnya dalam hal keamanan dengan ikut berjaga malam bersama warga, menghadiri undangan pernikahan, khitanan menjenguk orang sakit, takziyah, bersilaturrahim kepada para tokoh agama, khususnya pada event-event tertentu. Mengunjungi umat lain yang merayakan hari besarnya, misal Hindu saling mengunjungi umat lain yang merayakan hari raya seperti Natal dan Idul Fitri, sebailknya ketika hari raya Nyepi Umat Islam dan Kristiani juga mengunjungi umat Hindu ${ }^{49}$.

Disamping itu, menjaga komunikasi dengan baik agar saling mengenal dan tidak terjadi fanatisme terhadap agama sendiri juga penting dilakukan, dengan demikian umat diharapkan tidak mudah terprovokasi oleh isu-isu yang tidak bertanggung jawab, yang dapat memecah-belah hubungan antarumat beragama. Dalam konteks perayaan hari besar yang intinya adalah penyucian, menjelaskan agama Hindu yang merayakan hari raya Nyepi yang dalam ajaranya merupakan penyucian (Taur Agung). ${ }^{50}$

Kerukunan yang terjadi desa medowo antar umat beragama saling menghormati, menghoramti dalam bentuk membiarkan agama lain dalam menjalankan ibadah, menghormati dalam bentuk datang kerumah-rumah ketika hari raya besar, bentuk

\footnotetext{
49 Sumbulah, Pluralisme agama, 178.

${ }^{50}$ Ibid 153-154.
} 
toleransi hanya sebatas hubungan manusia satu dengan yang lain, bukan agama satu dengan yang lain, antara hindu, kristen dan islam tetap hidup bersamaan tapi bentuk kerukunanya bukan kerukunan akhidah tetapi kerukunan sosial, karena dalam islam diajarkan untukmu agamamu dan bagiku agamaku, yang dimaksud kerukunan bukan berati mengikuti ritual ibadah agama lain, jadi tetap ada batasanya. Walaupun berbeda agama tetapi tetap berdampingan.

Hal di atas sesuai dengan teori ploa kerukunan meyakini agama sendiri dan menghargai agama lain yaitu dengan cara memegang secara teguh keyakinan dan agama masing-masing. Secara universal, Islam adalah agama yang sangat menjunjung tinggi toleransi. Bahkan Nabi Muhammad tidak pernah mengajarkan dan merestui umatnya menyerang dan menghina keyakinan agama lain. ${ }^{51}$ Islam secara tegas memberikan kebebasan sepenuhnya kepada manusia dalam masalah agama dan keberagamaan. ${ }^{52}$

Mengenai sistem agama yang berbeda-beda, al-Qur'an menjelaskan pada ayat terakhir dalam surat Al-Kafirun:

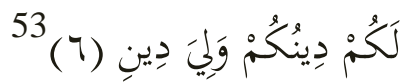

\section{6. untukmu agamamu, dan untukekulah, agamaku. ${ }^{154}$}

Bahwa prinsip menganut agama tunggal merupakan suatu keniscayaan. Tidak mungkin manusia menganut beberapa agama dalam waktu yang sama, atau mengamalkan ajaran dari berbagai agama secara silmutan. Oleh sebab itu, al-Qur'an menegaskan bahwa umat islam tetap berpegang teguh pada sistem ke-Esaan Allah secara mutlak, sedangkan orang kristen, Hindu pada ajaran ketuhanan yang ditetapkapkanya sendiri. Dalam ayat lain Allah juga menjelaskan tentang prinsip dimana setiap pemeluk agama mempunyai sistem dan ajaran masing-masing sehinga tidak saling hujat-menhujat."lanaa a'maluna walakum a'malukum"

Pada taraf ini konsepsi tidak menyinggung agama kita dan agama selain kita, juga sebaliknya. Dalam masa kehidupan dunia, dan untuk urusan dunia, semua haruslah kerjasama untuk mencapai keadilan, persamaan dan kesejahteraan manusia. Sedangkan untuk urusan akhirat, urusan petunjuk dan hidayah adalah hak mutlak Tuhan SWT. Maka

\footnotetext{
51 Ibid, 206

52 Ibid, 154.

53 Al-Kafirun: 6

${ }^{54}$ Departemen Agama RI, Al Qur'an dan Terjemahnya Special For Woman. (Jakarta: 2009),
} 
dengan sendirinya kita tidak sah memaksa kehendak kita kepada orang lain untuk menganut kita ${ }^{55}$.

Dalam kegiatan bersih desa atau ulang tahun desa, ada kegiatan yang namanya do'a bersama di saat itulah umat Islam, Hindu, Kristen, bukan duduk bersama-sama untuk berdo'a akan tetapi berdo'a bersama dengan waktu yang sama tapi tempatnya berbeda, umat kristen di balai desa, umat hindu di pure, dan yang islam di Masjid, sebelum berangkat ke tempat ibadah masing-masing mereka berkumpul di tempat yang sama untuk membuka acara, biasanya mengundang koramil dll. Besoknya lagi acara punden (berdoa dan nyekar) slametan di desa, semuanya membawa tumpeng di doakan dengan 3 macam agama mengundang semua warga untuk slametan bersama. Semua ini dilakukan di desa Medowo demi keberhasilan pembangunan di desa medowo, keamanan di desa Medowo dan kemakmuran desa Medowo.

Hal di atas sesuai dengan teori pola kerukunan yaitu Doa bersama merupakan salah satu medan budaya yang dapat mendukung kerukunan umat beragama. Hal ini misalnya kegiatan doa bersama yang dilakukan pada saat perayaan HUT RI tersebut, dilaksanakan sebagai rasa syukur kehadirat Tuhan Yang Maha Kuasa atas rahmat yang telah diberikan kepada seluruh umat manusia. Doa bersama yang dihadiri oleh para pemuka dari berbagai agama menunjukkan adanya persatuan yang kokoh, demi kemajuan bangsa Indonesia, yang diungkapkan dalam doa menurut agama dan keyakinan masingmasing.

\section{KESIMPULAN}

Materi pendidikan keagamaan yang dapat membentuk kerukunan umat beragama, meliputi; keimanan, ketaqwaan pada Tuhan, dan akhlak kepada sesamama manusia. Misal dalam hal keimanan membimbing umatnya untuk mencari ridho Tuhan dan kebahagaiaan di akhirat. Dalam hal sosial ahklah kepada sesama manusia, misalnya; gotong royong antar umat bergama, tidak menganggu ketika agama lain melaksanakan ibadah, dan yang sangat penting mengajarkan tetap berkeyakinan pada agama masing-masing. Kerukunan antar umat beragama di desa Medowo kecamatan Kandangan kabupaten Kediri dibuktikan dengan berbagai kegiatan. Setiap perayaan bersih desa (ulang tahun desa) melakukan do'a bersama. Dalam perayaan hari raya antar umat beragama saling membantu. Gotong royong dalam pembangunan rumah, jalan raya, pemakaman, serta kerja bakti desa.

\footnotetext{
55 Sumbulah, Pluralisme agama, 155.
} 


\section{REFERENSI}

Abu Abdullah, Muhammad bin Ismail. Shahih Bukhari. 4 ed. 1 vol. Beirut Lebanon: Dar al-Kotob Al-Ilmiyah, 2010.

Agus Ahmad Safei. "Dinamika Sosial Dalam Mewujudkan Toleransi Beragama (Studi Kasus Program Bandung Kota Agamis).” Doctoral, Universitas Padjadjaran, 2012. http://repository.unpad.ac.id/15951/.

Al-Qur`an. Jakarta: Kementerian Agama RI, 2010.

Arifin, Syamsul. "Islamic religious education and radicalism in Indonesia: strategy of deradicalization through strengthening the living values education.” Indonesian Journal of Islam and Muslim Societies 6, no. 1 (1 Juni 2016): 93. https://doi.org/10.18326/ijims.v6i1.93-126.

Bashori, Bashori. "Modernisasi Lembaga Pendidikan Pesantren Perspektif Azyumardi Azra." Nadwa 11, no. 2 (17 November 2017): 269. https://doi.org/10.21580/nw.2017.11.2.1881.

Benedict. Truth and Tolerance: Christian Belief and World Religions. San Francisco: Ignatius Press, 2004.

Bergen, C. W. Von. "Misconstrued tolerance: issues for multicultural and diversity training." Development and Learning in Organizations: An International Journal 27, no. 2 (8 Februari 2013): 9-12. https://doi.org/10.1108/14777281311302021.

Casram, Casram. "Membangun Sikap Toleransi Beragama dalam Masyarakat Plural." Wawasan: Jurnal Ilmiah Agama dan Sosial Budaya 1, no. 2 (2016): 187-198.

Dhavamony, Mariasusai. Fenomenologi agama. Yogyakarta: Kanisius, 2006.

Farer, Tom. "The Clash of Cultures, the Tension Within Liberalism, and the Proper Limits of Tolerance." Human Rights Quarterly 36, no. 1 (2014): 1-21. https://doi.org/10.1353/hrq.2014.0016.

Hady, Aslam. Pengantar Filsafat Agama. Rajawali, 1986.

Hayati, Nur Rohmah. "Pendidikan Pra Sekolah (Pendidikan Anak Usia Dini) Dalam Islam.” Aș-Ṣibyān: Jurnal Pendidikan Anak Usia Dini 1, no. 01 (25 Januari 2017): $72-82$.

Hermawati, Rina, Caroline Paskarina, dan Nunung Runiawati. "Toleransi Antar Umat Beragama di Kota Bandung." Indonesian Journal of Anthropology 1, no. 2 (23 Maret 2017). https://doi.org/10.24198/umbara.v1i2.10341.

Hidayat, Komaruddin. Psikologi Beragama. Hikmah, 2007. 
Hilmy, Masdar. "Whither Indonesia's Islamic Moderatism? A Reexamination on the Moderate Vision of Muhammadiyah and Nu." Journal of Indonesian Islam 7, no. 1 (1 Juni 2013): 24-48. https://doi.org/10.15642/JIIS.2013.7.1.24-48.

Husna, Khotimatul, Imam Ghozali, dan Dzulmanni. 40 hadits shabib: terapi nabi mengikis terorisme: teladan menebar kedamaian dan toleransi di muka bumi. Yogyakarta: Pustaka Pesantren, 2011.

Ikmal, Ikmal. "Internalisasi Nilai-Nilai Pluralisme dalam Pendidikan Islam." Jurnal Pendidikan Islam Iqra' 9, no. 1 (2018).

Ismail, Arifuddin. "Refleksi Pola Kerukunan Umat Beragama." Analisa: Journal of Social Science and Religion 17, no. 2 (2010): 175-186.

Johnson, Kristen Deede. Theology, political theory, and pluralism: beyond tolerance and difference. Cambridge studies in Christian doctrine, v. 15. Cambridge, UK; New York: Cambridge University Press, 2007.

Ma`arif, Muhammad Anas. "Internalisasi Nilai Multikulutural Dalam Mengembangkan Sikap Toleransi ( Studi Di Di Pesantren Mahasiswa Universitas Islam Malang).” Nazhruna: Jurnal Pendidikan Islam 2, no. 1 (24 Maret 2019). https://doi.org/10.31538/nzh.v2i1.179.

Malla, Hamlan Andi Baso. "Pembelajaran Pendidikan Agama Islam Berbasis Multikultural Humanistik Dalam Membentuk Budaya Toleransi Peserta Didik Di SMA Negeri Model Madani Palu, Sulawesi Tengah.” INFERENSI: Jurnal Penelitian Sosial Keagamaan 11, no. 1 (1 Juni 2017): 163-86. https://doi.org/10.18326/infsl3.v11i1.163-186.

Marimba, Ahmad D. Pengantar Filsafat Pendidikan Islam. P.T. Alma'arif, 1987.

Misrawi, Zuhairi, Mira Rainayati, dan Anjelita Noverina. Al-Quran kitab toleransi: tafsir tematik Islam rahmatan lil'alamîn. Jakarta: Pustaka Oasis, 2010.

Munawar, Said Aqil Husin Al, Hasan M. Noer, dan Musyafaullah. Hukum Islam dan pluralitas sosial. Penamadani, 2004.

Mursyid, Mursyid. "Internalisasi Nilai Keberagaman Agama Dan Paham Keislaman Di Pondok Pesantren: A Sociological Approaches.” Jurnal Kependidikan Islam 5, no. 2 (1 Agustus 2015): 125-48.

Nashir, Haedar, Zuly Qodir, Achmad Nurmandi, Hasse Jubba, dan Mega Hidayati. "Muhammadiyah's Moderation Stance in the 2019 General Election: Critical 
Views from Within." Al-Jami'ah: Journal of Islamic Studies 57, no. 1 (29 Juni 2019): 1-24. https://doi.org/10.14421/ajis.2019.571.1-24.

Neusner, Jacob, dan Bruce Chilton, ed. Religious tolerance in world religions. West Conshohocken, Pa: Templeton Foundation Press, 2008.

Perkembangan paham keagamaan transnasional di Indonesia. Kementerian Agama RI, Badan Litbang dan Diklat, Puslitbang Kehidupan Keagamaan, 2011.

Pramono, Agus, dan M. Ag Drs. M. Darojat Ariyanto. "Peran Forum Kerukunan Umat Beragama Dalam Membina Kerukunan Antar Umat Beragama (Studi Kasus FKUB Kota Surakarta).” S1, Universitas Muhammadiyah Surakarta, 2017. http://eprints.ums.ac.id/50007/.

Qomar, Mujamil. "Islam Nusantara: Sebuah Alternatif Model Pemikiran, Pemahaman, Dan Pengamalan Islam.” El Harakah (terakreditasi) 17, no. 2 (5 Februari 2016): 198-217. https://doi.org/10.18860/el.v17i2.3345.

Ramayulis. Ilmu Pendidikan Islam. Jakarta: Kalam Mulia, 2013.

Reid, Anthony. "Religious Pluralism or Conformity in Southeast Asia’s Cultural Legacy." Studia Islamika 22, no. 3 (2015): 387-404.

Rohmah, Nur, dan Dyah Fifin Fatimah. "Pola Pengelolaan Pendidikan Anak Usia Dini Di PAUD Ceria Gondangsari Jawa Tengah.” MANAGERIA: Jurnal Manajemen Pendidikan Islam 1, no. 2 (2016): 247-73. https://doi.org/10.14421/manageria.2016.12-05.

Sumbulah, Umi. Pluralisme agama: makna dan lokalitas pola kerukunan antarumat beragama. UIN-Maliki Press, 2013.

Supriyanto, Agus, dan Amien Wahyudi. "Skala karakter toleransi: konsep dan operasional aspek kedamaian, menghargai perbedaan dan kesadaran individu." Counsellia: Jurnal Bimbingan dan Konseling 7, no. 2 (30 November 2017): 61. https://doi.org/10.25273/counsellia.v7i2.1710.

Suryana, Toto. "Konsep dan Aktualisasi Kerukunan Antar Umat Beragama." Jurnal Pendidikan Agama Islam 9, no. 2 (2011): 127-136.

Zainuddin, M. Pluralisme agama dalam analisis konstruksi sosial. Cetakan III. Malang: UINMaliki Press, 2014. 